\title{
Audit Komunikasi Program Jogja Belajar Budaya
}

\author{
Fitri Trisnawati ${ }^{1}$, Puji Lestari ${ }^{2}$, Prayudi ${ }^{3}$ \\ 1,2,3 Program Studi Ilmu Komunikasi, Fakultas Ilmu Sosial dan Ilmu Politik, \\ Universitas Pembangunan "Veteran" Yogyakarta \\ Jl. Babarsari 2, Tambakbayan, Yogyakarta, 55281, Indonesia \\ Email: v3trizzna@yahoo.co.id ${ }^{1}$; puji.lestari@upnyk.ac.id ${ }^{2 *}$; prayudi@upnyk.ac.id ${ }^{3}$ \\ *Corresponding author
}

\begin{abstract}
One of contents the Privileges Law of Number 13/2012 concerning the Privileges Special Region Yogyakarta one of which a description the features education. This is a major challenge for the world of education in order to make Yogyakarta a leading culture-based education in Southeast Asia according to the philosophy Hamemayu Hayunig Bawana. Related to this, the Regional Government Yogyakarta launched Jogja Belajar Budaya program as an effort to carry out the vision education and preservation Jogja Culture. This research intend to the communication audit of the Jogja Belajar Budaya Program. The research method in this research is evaluative method with qualitative approach. The results is it shows that the communication audit of Jogja Belajar Budaya Program in general, on input stage have a good preparations, however there is a miss communication between practitioner and documentation; output stage, implementation of the program was running good showed by the expectations of this program was reached, however there are some problem be discovered. and the outcome stages the expectations of this program was reached, although there are people who can't feel the benefits of program.
\end{abstract}

Keywords: Communication Audit; Basic Elements Of Communication; Jogja Belajar Budaya; Pyramid Model Of Research

\begin{abstract}
Abstrak
Salah satu isi Undang-Undang Keistimewaan Nomor 13 Tahun 2012 tentang Keistimewaan Daerah Istimewa Yogyakarta adalah penjabaran keistimewaan tentang pendidikan. Hal ini menjadi tantangan besar dunia pendidikan guna mewujudkan Yogyakarta menjadi pendidikan berbasis budaya terkemuka di Asia Tenggara sesuai falsafah Hamemayu Hayunig Bawana. Terkait hal tersebut Pemda Daerah Iistimewa Yogyakarta (DIY) meluncurkan program Jogja Belajar Budaya sebagai salah satu upaya mengemban visi besar pendidikan dan pelestarian budaya Yogyakarta. Penelitian ini bertujuan melakukan audit komunikasi Program Jogja Belajar Budaya. Metode penelitian yang digunakan adalah metode evaluatif dengan pendekatan kualitatif. Hasil penelitian menunjukkan audit komunikasi Program Jogja Belajar Budaya pada secara umum tahap input konsep kegiatan terencana dengan baik, namun masih ada pemahaman program yang belum sejalan dengan dokumen perencanaan. Tahap output yang merupakan tahap pelaksanaan lancar terlihat dari tujuan program yang tercapai walaupun masih ditemukan beberapa kendala dalam pelaksanaan. Tahap outcome ditemukan bahwa tujuan besar program yang diharapkan belum tercapai dilihat dari hasil yang dapat merasakan kebermanfaatan program minim.
\end{abstract}

Kata kunci: Audit Komunikasi; Elemen Dasar Komunikasi; Jogja Belajar Budaya; Pyramid Model of Research

\section{Pendahuluan}

Pengesahan Undang-Undang Keistimewaan

Nomor 13 Tahun 2012 tentang Keistimewaan

Daerah Istimewa Yogyakarta menjadi tonggak sejarahbarubagikeberlanjutan pendidikan diDIY. Meskipun tidak secara eksplisit diatur tentang keistimewaan bidang pendidikan, namun secara implisit terdapat tugas besar bidang pendidikan untuk mengisi substansi keistimewaan Daerah Istimewa Yogyakarta. Aturan inilah yang menjadi tantangan serta tanggung jawab besar bagi pemerintah daerah dan masyarakat. Aturan tersebut diwujudkan dengan memberikan konten yang istimewa pada kebijakan pendidikan DIY. Cara ini relevan karena pengisian substansi keistimewaan memang tidak bisa terlepas dari kebijakan itu sendiri. 
Tabel 1 Pembelajaran yang Dianggap Bermanfaat oleh Guru

\begin{tabular}{|c|c|c|}
\hline Jawaban & Presentase & Kategori \\
\hline JB radio. & 40.95 & Kadang \\
\hline JB budaya & 45.71 & Kadang \\
\hline JB tube. & 46.35 & Kadang \\
\hline JB media & 46.67 & Kadang \\
\hline Media pembelajaran berbasis android & 47.78 & Sering \\
\hline JB class & 53.02 & Kadang \\
\hline Media berbasis animasi & 66.19 & Sering \\
\hline Konten pembelajaran ICT EQEP & 66.19 & Sering \\
\hline Media berbasis audio & 71.27 & Sering \\
\hline Media berbasis multimedia & 73.33 & Sering \\
\hline
\end{tabular}

Sumber: Prasurvei Peneliti (2018)

Upaya pengembangan pendidikan terus digali melalui kebijakan dengan mengacu kepada branding Kota Yogyakarta sebagai Kota Pelajar. Perolehan predikat Kota Pelajar tidak bisa lepas dari sejarah gerakan pendidikan formal yang tumbuh dan berkembang di DIY. Peran Sekolah Tamanan dan Sekolah Madya di Kraton Yogyakarta sejak tahun 1848 menjadi titik awal pendidikan formal di DIY meskipun saat itu hanya diperuntukkan untuk keluarga Kraton. Perkembangan sekolah ini menjadi cikal bakal pendidikan formal yang saat ini ada yaitu Sekolah Dasar (SD), Sekolah Menengah Pertama (SMP), dan Sekolah Menengah Atas (SMA). Menyinggung tentang keistimewaan DIY bahwa esensi keistimewaan pendidikan di DIY terletak pada pendidikan berbasis budaya sebagai simbol kekhasan DIY. Pendidikan berbasis budaya diasumsikan sebagai pengelolaan dan penyelenggaraan pendidikan berdasar Sistem Pendidikan Nasional dengan menjunjung tinggi nilai luhur budaya. Budaya yang dimaksud budaya DIY dengan tetap mangapresiasi budaya nasional. Langkah ini dilakukan sebagai upaya penanaman tata nilai budaya dalam diri anak didik melalui strategi implementasi nilai Budaya Yogya dalam sendi kehidupan seharihari. Pada zaman dulu nilai budaya mampu dijadikan pilar utama pembentukan karakter anak didik. Hal ini yang ingin diwujudkan agar cita - cita Yogyakarta mampu menjadi "Indonesia Mini", Yogyakarta menjadi pusat pendidikan terkemuka dan Yogyakarta menjadi hamemayu hayuning Bawana.
Falsafah Hamemayu Hayuning Bawana telah digagas sejak Sri Sultan Hamengku Buwono I. Falsafah inilah yang dijadikan sebagai visi, golong giling sebagai penyemangat dan sebagai watak satriya Yogyakarta berpegang pada falsafah sawiji, greget, Sengguh ora mingkuh. Pemahaman ketiga falsafah tersebut perlu diimplementasikan dalam pendidikan dan pembelajaran guna pembentukan watak manusia berbudaya, berbudi pekerti luhur dan mampu mengembangkan budayanya sendiri. Pembelajaran inilah yang dilaksanakan melalui pembelajaran berbasis budaya. Pembelajaran dibedakan melalui tiga macam belajar tentang budaya (menempatkan budaya sebagai bidang ilmu), belajar dengan budaya (metode pemanfaatan budaya), belajar melalui budaya (pemahaman makna yang diciptakan baik melalui kreativitas maupun imajinasi dalam ragam perwujudan budaya). Sejalan dengan Tri Pusat pendidikan bahwa pendidikan dilaksanakan dalam keluarga, sekolah dan masyarakat sehingga internalisasi pendidikan berbasis budaya dilakukan melalui jalur ini. Filosofi ini sangat bagus jika mampu diterapkan dalam kehidupan masyarakat. Artinya semua memikul tanggung jawab guna perwujudan tujuan mulia.

Seiring perjalanan waktu filosofi yang dipegang teguh sedikit demi sedikit luntur karena perkembangan teknologi yang begitu pesat tanpa diiringi gerakan mencintai budaya sendiri. Inilah yang menjadi keprihatinan bangsa bahwa generasi muda tidak mengenal budaya nenek moyang yang nyata jika diterapkan akan terjadi kehidupan yang damai. 
Tabel 2 Frekuensi Penggunaan

\begin{tabular}{lcc}
\hline \multicolumn{1}{c}{ Jawaban } & Prosentase & Kategori \\
\hline JB radio. & 31.11 & Jarang \\
Media pembelajaran berbasis android & 35.08 & Jarang \\
JB budaya & 35.24 & Jarang \\
JB tube & 36.67 & Jarang \\
JB class & 39.84 & Jarang \\
Media berbasis multimedia & 40.79 & Kadang \\
Konten pembelajaran ICT EQEP & 50.79 & Kadang \\
Media berbasis audio & 50.95 & Kadang \\
Media berbasis animasi & 51.75 & Kadang \\
Media pembelajaran berbasis video & 55.87 & Sering \\
\hline
\end{tabular}

Sumber: Prasurvei Peneliti (2018)

Fenomena lunturnya esensi kejawen ditandai sikap generasi muda yang tidak tahu dan tidak mau tahu dengan budaya nenek moyang. Sopan santun, unggah-ungguh tidak lagi diterapkan dalam hidup bermasyarakat. Penggunaan Bahasa Jawa juga sangat minim dalam kehidupan sehari- hari ditambah adanya kebijakan bahwa Bahasa Jawa hanya dimasukkan sebagai mata pelajaran muatan lokal dan tidak menduduki dalam mata pelajaran penting.

Sebenarnya pemerintah juga memikul tanggung jawab agar mampu memposisikan Budaya Jogja sebagai budaya tinggi dan memang harus ditinggikan. Terkait kebijakan pelajaran Bahasa Jawa sebagai muatan lokal perlu ditinjau ulang guna penanaman budaya Jawa dalam kehidupan sehari- hari. Langkah yang bisa diambil pemerintah guna perlindungan Budaya Jawa juga dapat dilakukan melalui program yang dibutuhkan masyarakat dengan asumsi mampu menumbuhkan rasa cinta budaya.

Langkah nyata Pemerintah Daerah DIY diwujudkan dengan peluncuran program Jogja Belajar Budaya. Program ini dirilis tahun 2014 oleh Balai Teknologi Komunikasi Pendidikan Dinas Pendidikan Pemuda dan Olahraga DIY. Program Jogja Belajar Budaya berisi konten berbagai macam Budaya Jogja agar dapat dinikmati semua orang yang membutuhkan. Internet dipilih sebagai media yang dianggap paling efektif. Pemilihan media dilatar belakangi pesatnya perkembangan teknologi informasi dan komunikasi (TIK) yang menjadikan internet sebagai media komunikasi utama masyarakat. Perubahan teknologi komunikasi dari konvensional menjadi modern dan serba digital diharapkan mampu mengantarkan program Jogja Belajar Budaya di puncak kejayaannya. Hadirnya media ini menjadikan fasilitas yang disediakan dalam berkomunikasi semakin beraneka ragam. Salah satunya program Jogja Belajar Budaya yang bisa diakses kapanpun dan dimanapun dengan harapan mampu mendongkrak visi pendidikan DIY mewujudkan pendidikan berbasis budaya terkemuka di asia tenggara 2025 .

Langkah perwujudan visi besar ternyata tidak semudah yang direncanakan. Pra survei yang dilakukan terdapat indikasi bahwa program Jogja Belajar Budaya belum mampu menjadi seperti yang diinginkan. Pra survei dilakukan peneliti kepada 250 sekolah penerima bantuan ICT EQEP ternyata kurang memauaskan. Dipilihnya sekolah ini karena diasumsikan penerima bantuan ICT EQEP lebih tahu dan mengenal program Balai Tekkomdik. Prasurvei dalam bentuk kuesioner dilaksanakan di bulan September 2018 (Tabel 1 dan tabel 2).

Tabel 1 memperlihatkan program yang menjadi andalan Pemda DIY ternyata masih belum seperti yang diharapkan. Program Jogja Belajar Budaya dalam kategori pembelajaran yang dianggap bermanfaat oleh guru ternyata hanya $45,71 \%$ sehingga hanya masuk dalam kategori sedang. Artinya bahwa hanya 45,7\% guru 
menyatakan bahwa program Jogja Belajar Budaya bermanfaat. Jadi manfaat yang bisa dirasakan belum mencapai setengah dari seluruh responden.

Tabel 2 merupakan tabel hasil monitoring kepada guru dengan kategori frekuensi penggunaan media pembelajaran. Hasilnya menunjukkan frekuensi penggunaan Jogja Belajar Budaya hanya 35,24\% saja atau dalam kategori jarang. Berarti jumlah pengakses program ini masih minim dibandingkan dengan target pemanfaatannya. Hal ini dikuatkan dengan melihat jumlah visitor di tahun 2018 hanya 1175 kali dikunjungi. Artinya adanya kesesuaian antara hasil monitoring dengan jumlah visitor yang menguatkan bahwa program Jogja Belajar Budaya memang jarang diakses.

Jika jumlah visitor minim artinya pesan yang ingin disampaikan dari program Jogja Belajar Budaya selaku komunikator melalui media internet tidak akan sampai kepada target pengguna/komunikan. Artinya terdapat gangguan dalam proses komunikasi. Sesuai teori teori komunikasi model David K. Berlo atau lebih dikenal dengan model SMCR. Model ini mengacu bahwa proses komunikasi dipengaruhi oleh Source (sumber), Message (pesan), Channel (Saluran), dan Receiver (penerima). Oleh sebab itu tantangan bagi peneliti untuk dapat mencari letakgangguan dalam proses komunikasi tersebut.

Fenomena komunikasi inilah yang menarik untuk diteliti guna mencari sumber kemacetan. Audit komunikasi menjadi pilihan yang tepat untuk memberikan solusi permasalahan yang ada karena dalam audit komunikasi merupakan kajian ilmiah dalam rangka mendiagnosis seluruh proses komunikasi. Audit komunikasi diharapkan kehadirannya mampu memberikan pemecahan masalah dengan adanya rekomendasi.

Penelitian terkait audit komunikasi sudah dilakukan oleh Ramadani, Lestari, dan Susilo (2015). Penelitian tersebut menganalisis audit komunikasi Organisasi Wahana Lingkungan Hidup Indonesia (WALHI) Yogyakarta. Menggunakan lima unit analisis yaitu organisasi, muatan informasi, manajemen, proses komunikasi atau kegiatan-kegiatan komunikasi, dan umpan balik, hasil penelitian menunjukkan proses pelaksanaan audit komunikasi organisasi WALHI Yogyakarta sudah berjalan cukup baik.

Penelitian lain yaitu Audit Komunikasi Organisasi Horisonal Departemen Front Office Singgasana Hotel Surabaya oleh Panghegar (2013). Penelitian tersebut menjabarkan jenis komunikasi horizontal, tujuan komunikasi horizontal, serta hambatan di dalamnya. Hasil menunjukkan komunikasi horizontal departemen FO Singgasana Hotel Surabaya berjalan baik. media komunikasi yang digunakan cukup beraneka ragam yang disesuaikan dengan tujuan komunikasi. namun masih ditemukan beberapa hambatan seperti hambatan lingkungan, SDM, dan tugas serta tanggung jawab individu.

Koesmastuti (2015) melakukan penelitian tentang audit komunikasi dalam organisasi budaya Timur. Penelitian ini menemukan bahwa budaya suatu daerah sangat memengaruhi perilaku individu. Pengaruh ini terjadi bukan hanya pada perilaku sehari-hari, melainkan juga perilaku pada organisasi professional. Diperlukan penyesuaian dalam proses audit komunikasi pada organisasi berlatar belakang budaya timur. Pengaruh budaya pada perilaku komunikasi anggota juga berdampak positif untuk meningkatkan efektivitas organisasi.

Selain itu dari beberapa penelitian yang ada, peneliti belum menemukan penelitian tentang program Jogja Belajar Budaya. Hasil pra survei yang diperoleh menjadikan peneliti peneliti ingin mengetahui lebih banyak tentang kemanfaatan dari program Jogja Belajar Budaya. Selama ini penelitian audit komunikasi tentang komunikasi internal ataupun komunikasi organisasi. Oleh karena itu penelitian tentang audit komunikasi program Jogja Belajar Budaya menjadi penting agar dapat memberikan masukan guna perbaikan program dan kehadirannya agar mampu menempatkan program ini dalam posisi yang diinginkan demi pencapaian visi pendidikan berbasis budaya terkemuka di Asia Tenggara. 
Berdasarkan dari latar belakang maka tujuan penelitian ini adalah: (1) mengetahui ketercapaian komunikasi persiapan (input) program Jogja Belajar Budaya di Balai Teknologi Komunikasi Pendidikan Dinas pendidikan Pemuda dan Olahraga Provinsi Daerah istimewa Yogyakarta, (2) mengetahui ketercapaiann komunikasi pelaksanaan (output) program Jogja Belajar Budaya di Balai Teknologi Komunikasi Pendidikan Dinas pendidikan Pemuda dan Olahraga Provinsi Daerah istimewa Yogyakart, dan (3) mengetahui ketercapaian komunikasi dampak (outcome) pelaksanaan Program Jogja Belajar Budaya di Balai Teknologi Komunikasi Pendidikan Dinas pendidikan Pemuda dan Olahraga Provinsi Daerah istimewa Yogyakarta

\section{Audit Komunikasi}

Audit komunikasi merupakan kajian ilmiah dan profesional yang dapat disamakan dengan diagnosiskesehatan dalamgeneral checkup dokter atau audit keuangan oleh akuntan tersertifikasi. Audit komunikasi dilakukan mengikuti kaidah penelitian ilmiah dan mempunyai tujuan khusus, menghasilkan rekomendasi untuk memperbaiki atau mengubah kebijakan atau sistem komunikasi organisasi yang berdampak pada perubahan disesuaikan kebutuhan kondisi internal maupun eksternal (Hardjana:2000).

Model-model dominan audit komunikasi yang dapat dimasukan dalam 3 (tiga) kategori sebagai berikut: (1) Model struktur konseptual, adalah audit komunikasi keorganisasian dalam hubungannya antara maksud, tujuan akhir komunikasi organisasi dalam rangka pencapaian tujuan organisasi, tata kerja atau prosedur pelaksanaan meliputi pemanfaatan jaringan komunikasi, adopsi kebijakan komunikasi dan pelaksanaannya dan struktur organisasi yang mencakup unit kerja, jaringan komunikasi fungsional, kebijakan dan kegiatan komunikasi. (2) Model profil keorganisasian, merupakan model analisis fungsional sistem organisasi untuk memeriksa keadaan masa kini agar diketahui kesalahan yang terjadi dan menemukan jalan yang dapat dipergunakan untuk memperbaikinya, sehingga efektifitas organisasi dapat tercapai. Unsur yang perlu diperiksa adalah komunikasi, peran dan fungsi anggota dalam kelompok, pemecahan masalah dan pengambilan keputusan, norma dan pertumbuhan kelompok, kepemimpinan dan kewenangan, kerjasama maupun persaingan antar kelompok. (3) Model evaluasi komunikasi, meliputi pemeriksaan dan penilaian, praktik dan kegiatan komunikasi. Informasi yang didapat dijadikan dasar pembanding manajemen guna perbaikan sistem komunikasi internal dan eksternal, perbaikan dalam perencanaan dan pengendalian manajemen dan menjembatani sistem komunikasi. (Hardjana , 2000: 40-58)

Model evaluasi komunikasi menjadi pilihan penelitian ini karena model ini mencakup penilaian dari perencanaan dan pengendalian untuk perbaikan sistem komunikasi baik internal maupun eksternal

\section{Audit Komunikasi di Instansi Pemerintahan}

Guna mencapai visi, misi, dan tujuannya, instansi pemerintah melakukan aktivitas operasional sehari-hari. Dalam penyelenggaraan pelayanan publik, instansi pemerintah berinteraksi dengan publik atau pihak lain. Pemerintah selalu berusaha untuk menampilkan profil penyelenggaraan pelayan publik terbaik. Tujuannya supaya publik selaku mitra layanan mendapatkan kepuasan. Namun pada kenyataannya tak jarang terjadi kesenjangan antara pesan yang dikomunikasikan oleh instansi pemerintah dengan persepsi dan harapan publik. Umumnya kesenjangan komunikasi yang terjadi berdampak pada persoalan kepercayaan (trust). Akibatnya proses komunikasi yang berlangsung dapat menimbulkan kesalahpahaman. Kondisi ini dapat berpengaruh pada efektifitas dan kinerja instansi pemerintah di dalam pencapaian visi, misi, dan tujuannya. Perlu diadakan audit komunikasi dengan tujuan meningkatkan 


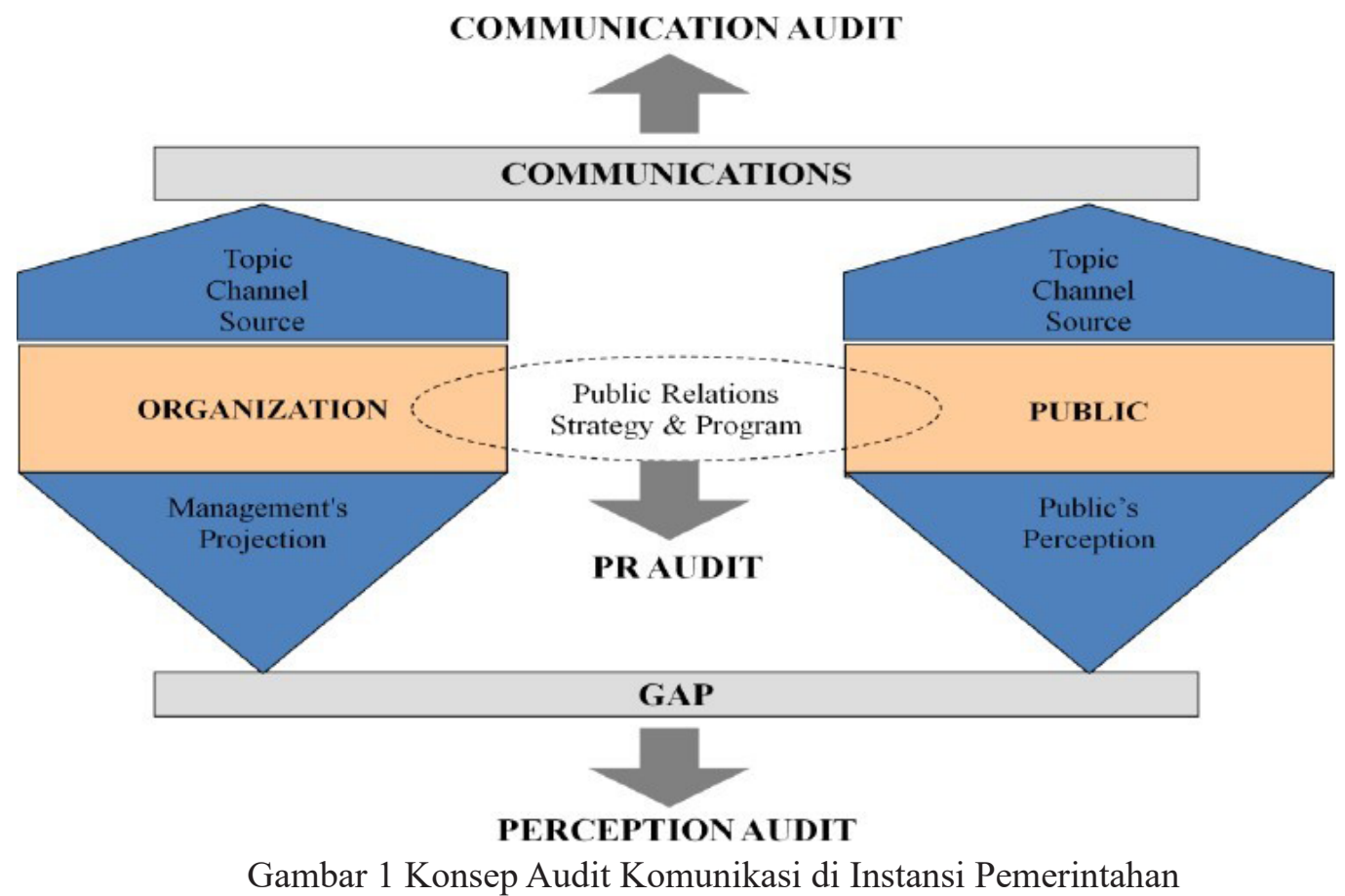

Sumber: Peraturan menteri Pendayagunaan Aparatur Negara dan Reformasi Birokrasi Nomor 27 Tahun 2011

efektifitas sistem dan proses komunikasi humas pemerintah. Audit komunikasi mengukur, menganalisis, serta mengevaluasi secara mendalam dan menyeluruh terhadap sistem serta proses komunikasiinstansi pemerintahan. Berikut konsep audit di instansi pemerintah (gambar 1).

\section{Metode Penelitian}

Penelitian ini merupakan penelitian kualitatif studi kasus (case study). Studi kasus adalah suatu penelitian yang diarahkan untuk menghimpun data, mengambil makna, memperoleh pemahaman dari kasus tersebut. Kasus yang diangkat dalam penelitian ini adalah audit komunikasi program Jogja Belajar Budaya Balai Tekkomdik Dinas Dikpora DIY.

Subjek penelitian ini adalah informan yang berasal dari berbagai pihak, antara lain kepala Balai Tekkomdik DIY, pengembang teknologi pembelajaran, programmer, admin Jogja Belajar Budaya. direktur JB Radio, guru SMA, Pegawai Balai Tekkomdik selaku pemegang anggaran, dan tim teknis Balai
Tekkomdik. Sedangkan objek dalam penelitian ini adalah audit komunikasi program JB Budaya Balai Teknologi Komunikasi Pendidikan Dinas Pemuda dan Olahraga provinsi DIY.

Data primer diperoleh melalui wawancara. Data sekunder dalam penelitian ini diperoleh dari arsip dan dokumentasi serta data observasi terkait program Jogja Belajar Budaya (Moleong, 2008). Teknik pengumpulan data yaitu dengan wawancara, dokumentasi dan observasi. Teknik analisa data melalui beberapa tahap, yaitu (1) merangkum memilih hal-hal yang pokok, memfokuskan pada hal-hal yang penting dan dicari tema dan polanya, (2) menyusun kembali data berdasarkan klasifikasi dan masing-masing topik dipisahkan, kemudian topik yang sama disimpan dalam satu tempat, masing- masing tempat diberi kode, (3) data yang dikelompokkan yang sesuai dengan topiktopik, kemudian diteliti kembali dengan cermat, mana data yang sudah lengkap dan mana data yang belum lengkap yang masih memerlukan data tambahan, dan (4) menyusun laporan hingga pada akhirnya pembuatan kesimpulan. 
Metode penelitian audit komunikasi juga memiliki prosedur yang harus dilalui peneliti sehingga persyaratan ilmiah dapat dipenuhi. Prosedur atau tahapan perlu diuraikan dan dilakukan dalam audit komunikasi. Berkaitan dengan tahap-tahap penelitian audit komunikasi, Agensi Joyece F.Jones dan Ruder Finn Rotman yang dikutip Bakin, Aronoff \& Lattimore (1997: 124) membaginya menjadi empat tahap yaitu 1. Menyelidiki apa yang "kita" pikirkan; 2. Menyelidiki apa yang "mereka" pikirkan; 3. Mengevaluasi perbedaan antara dua sudut pandang; 4. Menganjurkan atau merekomendasikan program komunikasi yang komprehensif dengan tujuan untuk mengakhiri kesenjangan tersebut; 5. Prosedur tersebut menjadi sebuah acuan pelaksanaan sebuah audit yang benar dalam penelitian audit komunikasi pada program Jogja Belajar Budaya.

Metode analisis data menggunakan Pyramid model of research merupakan salah satu model evaluasi dalam public relation. Model ini digambarkan dengan sebuah piramida dan terbagi dalam tiga tahapan, yaitu tahap input, tahap output dan tahap outcome. Model piramida memberikan arahan bahwa tahap input berada paling bawah merupakan komponen fisik program komunikasi misalnya pilihan media, konten dan format. Secara garis besar tahap input mengevaluasi tentang perencanaan program dengan harapan semua aspek dapat dilihat agar bisa memperoleh data yang diinginkan. Tahap berikutnya dalam pyramid model of research digambarkan berada di atas tahap input. Tahapan ini mengulas tentang jumlah ataupun banyaknya pesan yang telah tersampaikan kepada komunikan melalui kegiatan yang produksi dan prosesnya. Tahapan ini berusaha memotret sejauh mana pesan tersampaikan beserta media yang digunakan. Tahap outcome merupakan tahap terakhir dari pyramid model of research yang berada di posisi teratas dengan jumlah paling sedikit. Tahapan ini merupakan tahap guna melihat dampak yang dihasilkan dari proses input maupun proses output. Terkait program Jogja Belajar Budaya maka dampak yang ingin dilihat adalah kebermanfaatan adanya program Jogja Belajar Budaya.

Model piramida ini instruktif dan praktis karena berusaha menyajikan daftar metodologi riset untuk tiap tahapan. Model Piramida riset dilakukan sebelum, selama dan setelah kegiatan komunikasi sehingga dapat mengidentifikasi, memahami dan mengakomodasi kebutuhan, minat dan sikap khalayak, serta agar praktisi dapat melakukan patokan sebelum dan setelah implementasi. Model riset piramida menerapkan evaluasi sistem tertutup (closed system evaluation) dan evaluasi sistem terbuka (open system evaluation). Sistem evaluasi tertutup terfokus pada pesan-pesan dan event kampanye serta efeknya terhadap khalayak yang dituju. Sedangkan sistem evaluasi terbuka mengukur dampak diluar program. Metode ini mengutamakan untuk mencapai efektivitas organisasi secara keseluruhan. Kombinasi dua sistem ini merupakan perpaduan yang baik untuk mengukur efektivitas kinerja Public Relations (Prayudi: 2016).

\section{Hasil Penelitian dan Pembahasan Profil Balai Tekologi Komunikasi Pendidikan Dinas Pendidikan, Pemuda, dan Olahraga Provinsi DIY}

Balai Teknologi Komunikasi Pendidikan (BTKP) merupakan instansi pemerintah yang berfokus pada pemanfaatan IT. Kantor ini menjadi salah satu UPT Dinas Pendidikan Pemuda dan Olahraga Provinsi Daerah Istimewa Yogyakarta yang dulunya bernama Sanggar Tekkomdik dan berada di bawah kewenangan Pustekkom Depdiknas Jakarta. Balai Tekkomdik mengusung visi "menjadi pusat sumber belajar pendidikan formal dan non formal jenjang pendidikan dasar dan menengah berbasis teknologi informasi dan komunikasi terkemuka di Asia Tenggara Tahun 2025". Adanya visi tersebut diharapkan mampu memotivasi agar 
mampu mewujudkan mimpi di waktu yang akan datang. Misi Balai Tekkomdik orientasinya memberantas buta komputer bagi pendidik dan tenaga kependidikan pada jenjang pendidikan dasar dan menengah. Pengembangan dan roduksi materi atau bahan pembelajaran berbasis TIK bagi dunia pendidikan diharapkan dapat membantu mempermudah transfer pengetahuan khusunya TIK bagi pembelajaran. Selain itu jalur yang ditempuh guna memasyarakatkan produk balai dilakukan dengan promosi serta memberikan layanan teknis pemanfaatan TIK. Balai Tekkomdik juga membuka ruang konsultasi untuk umum di bidang penggunaan TIK baik untuk sekolah maupun luar sekolah.

\section{Program Jogja Belajar Budaya}

Jogja Belajar merupakan unggulan Digital Goverment Service's sebagai bagian Jogja Cyber Province, mencakup layanan meliputi muatan pembelajaran multimedia, audio, video, muatan budaya dan layanan pembelajaran secara online, kapanpun dan dimanapun.

Keseluruhan muatan Jogja Belajar diharapkan dapat memberikan kontribusi besar bagi visi pendidikan di DIY yaitu membangun pendidikan berkarakter dan berbudaya dengan mewujudkan Yogyakarta sebagai pusat pendidikan berbasis budaya yang terkemuka di Asia Tenggara pada tahun 2025.

Layanan strategis dalam portal jogja Belajar yang bisa diakses meliputi Jogja Belajar Radio (JB Radio), Jogja Belajar Tube (JB Tube), Jogja Belajar Media (JB Media), Jogja Belajar Class (JB Class) dan Jogja Belajar Budaya (JB Budaya).

Program Jogja Belajar Budaya tidak bisa lepas dari dunia pendidikan. Diharapkan semua materi yang tertuang di dalam Jogja Belajar Budaya mampu memenuhi bahkan menopang kelancaran proses belajar mengajar di sekolah sesuai kurikulum yang berlaku. Artinya target Jogja Belajar Budaya memenuhi semua kebutuhan masyarakat dan juga bidang pendidikan khususnya Bahasa Jawa.
Hasil audit komunikasi Program Jogja Belajar Budaya sebagai salah satu upaya pelestarian budaya Jogja dengan mewujudkan misi pendidikan berbasis budaya. Pendidikan berbasis budaya diasumsikan sebagai upaya penanaman tata nilai budaya. Hal ini merupakan langkah strategis implementasi nilai budaya Jogja kedalam sendi kehidupan masyarakat yang telah terwujud di masa lampau.

Sejalan dengan hal itu Pemda DIY meluncurkan Program Jogja Belajar Budaya. Berpedoman pada konsep Tri pusat pendidikan yaitu keberhasilan pendidikan menjadi tugas keluarga, sekolah dan masyarakat. Hal ini terlihat dari target yang ditetapkan dalam Program Jogja Belajar Budaya bukan hanya anak didik ataupun guru, namun masyarakat secara umum.

Sesuai Peraturan Menteri Negara Pendayagunaan Aparatur Negara dan Reformasi Birokrasi Republik Indonesia Nomor 27 Tahun 2011 Tentang Pedoman Umum Audit Komunikasi di Lingkungan Instansi Pemerintah disebutkan adanya dimensi audit komunikasi instansi pemerintah. Untuk mempermudah proses audit komunikasi Program Jogja Belajar Budaya, peneliti menggunakan pedoman Pyramid Model Of Research. Model ini digabungkan dengan dimensi audit komunikasi sehingga muncul dalam tiap tahapan input, output maupun outcome dengan memiliki masing- masing indikator.

Pada dasarnya audit ini dilakukan untuk mencari manfaat ataupun kendala Program Jogja Belajar Budaya dengan melakukan audit komunikasi. Dengan kata lain peneliti mengadakan audit karena selama Program Jogja Belajar Budaya terbentuk belum pernah dilakukan audit/ evaluasi melalui audit komunikasi sehingga dianggap penting untuk bisa memberikan gambaran keadaan Program Jogja Belajar Budaya yang sebenarnya. Evaluasi penting dilakukan setiap program karena mendapatkan data guna mengetahui efektivitas sebuah program. Hasil evaluasi menjadi patokan apakah program dilanjutkan, dihentikan atau 


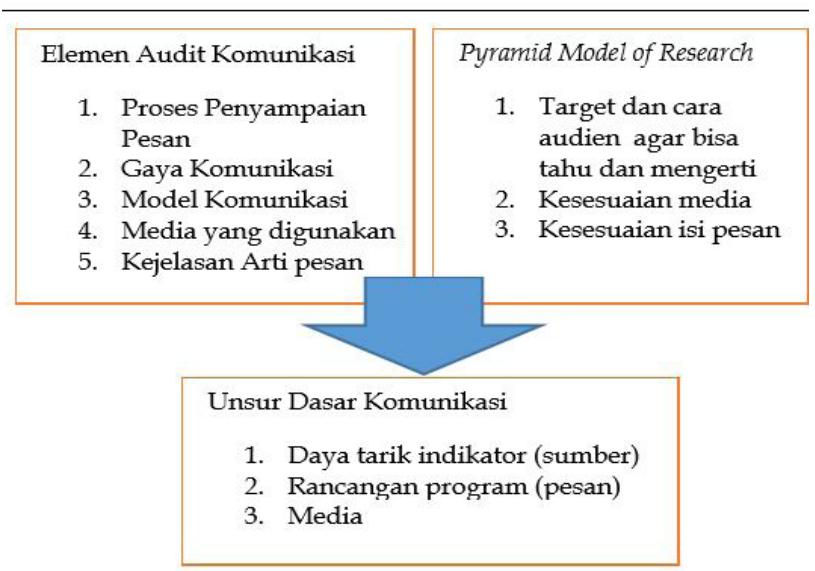

Gambar 2. Audit Program Jogja Belajar Budaya Tahap Input

mungkin dilanjutkan dengan menerapkan strategi baru agar mendapatkan hasil terbaik dari program yang dijalani. Evaluasi merupakan proses penilaian berdasarkan standar dan tujuan. Standar adalah hasil yang diinginkan, dengan cara membandingkan tujuan dengan hasil.

Berdasarkan hasil audit yang dilakukan peneliti, audit komunikasi Program Jogja Belajar Budaya Balai Tekkomdik secara umum sudah berjalan sesuai perencanaan. Hal ini dibuktikan beberapa pernyataan positif dari informan. Di sisi lain ditemukan juga pernyataan negatif dari informan yang diharapkan menjadi perhatian tim Program Jogja Belajar Budaya agar menjadi masukan untuk kedepan lebih baik.

\section{Evaluasi Tahap Input}

Audit pada tahapan input dikaji dengan menggunakan indikator penggabungan antara dimensi audit komunikasi dengan Pyramid Model Of Research. Penggabungan dua model tersebut dapat diringkas menjadi gambar 2 .

Gambar 2 menunjukkan bahwa sebenarnya elemen unsur dasar komunikasi telah mencakup dalam elemen audit komunikasi maupun dalam Pyramid Model Of Research. Hasil audit menunjukkan secara umum tahapan input telah sesuai dengan perencanaan. Hal ini dibuktikan dengan hasil penelitian dari elemen (1) Gaya komunikasi. elemen ini memberikan bukti bahwa 44\% informan menyatakan gaya komunikasi yang diterapkan Program Jogja Belajar Budaya menarik dan informatif. Beberapa informan memberikan pernyataan senada dengan menyatakan bahwa: "Program Jogja Belajar Budaya menarik, tampilan bagus, menyuguhkan konten menarik, informatif, membuat yang tadinya malas membaca menjadi mau membaca. Namun begitu alangkah lebih baiknya jika dilengkapi dengan gambar pendukung agar lebih baik lagi (wawancara N tanggal 16 Juli 2019)" Hasil wawancara tersebut merupakan pernyataan positif namun juga ada catatan yang harus diperhatikan yaitu kurangnya gambar pendukung. Hal ini sesuai dengan hasil audit informan yang menyatakan bahwa tampilan Program Jogja Belajar Budaya monoton dan kurang sesuai. Jumlah informan yang mengatakan hal itu hanya $12 \%$ saja. Secara umum hasil audit gaya komunikasi yang diterapkan sebagai upaya menarik komunikan telah tercapai meskipun ada catatan sebagai perbaikan, yaitu: (1) penambahan gambar, video, animasi ataupun tari- taria agar lebih menarik, (2) isi pesan dilengkapi dan disesuaikan dengan kurikulum atau kebutuhan, dan (3) ketepatan penggunaan media.

Audit guna melihat ketepatan penggunaan media Program Jogja Belajar Budaya dilakukan dengan mengaudit dokumen dan wawancara. Informan yang diwawancarai hanya memiliki dua alternatif yaitu tepat dan kurang tepat. Hasil audit wawancara menunjukkan pemilihan media Program Jogja Belajar Budaya 46\% informan menyatakan tepat. Jadi secara umum hampir setengah informan mengatakan media melalui internet yang digunakan Program Jogja Belajar Budaya telah tepat. Hasil audit yang lain ada 32\% informan mengatakan media Program Jogja Belajar Budaya kurang tepat. Alasan yang banyak diutarakan mereka memilih media lain yang tidak harus menggunakan data internet. Misalnya dengan aplikasi offline tertentu sehingga tidak boros 


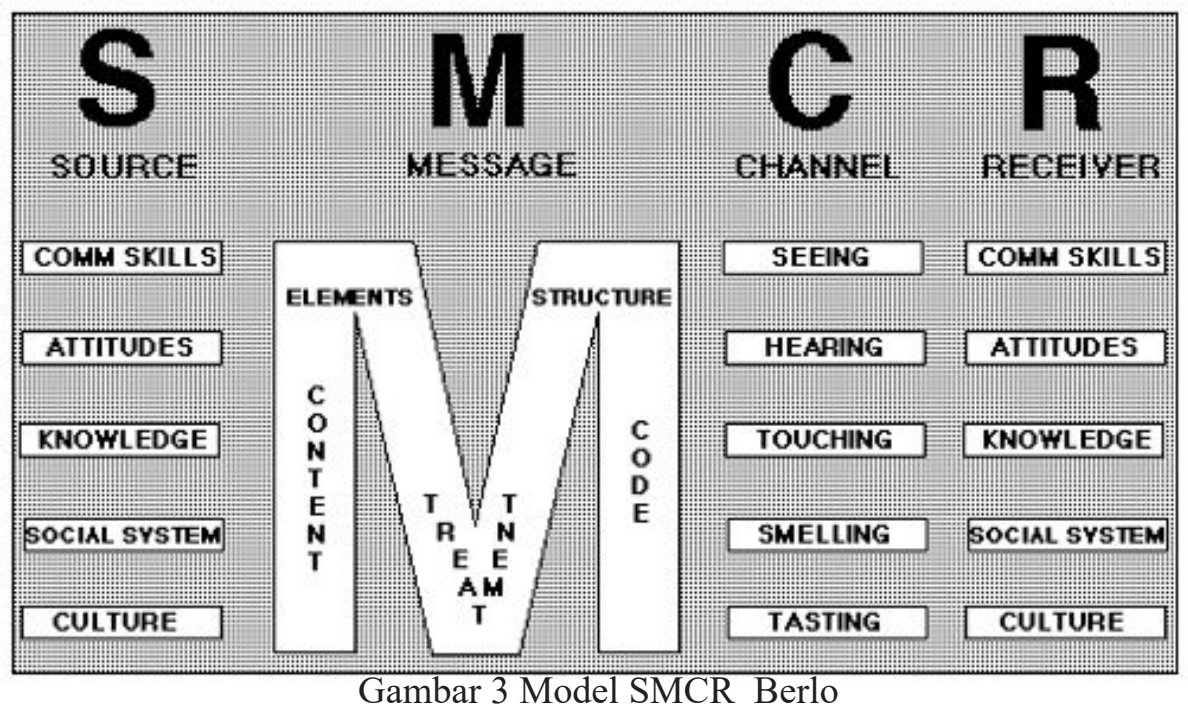

Sumber: http://www.managementstudyguide.com/berlo-model-of-communication.htm

kuota. Ada juga yang menyatakan Program Jogja Belajar Budaya dipindah ke media sosial seperti Instagram dan Facebook dengan alasan media sosial tersebutbanyak digunakan semua kalangan. Dipindahkannya Program Jogja Belajar Budaya melalui media sosial diharapkan akan menambah jumlah pengunjung demi pencapaian tujuan.

Hasil audit selanjutnya terdapat $22 \%$ informan menyatakan kurang merespon ketika diminta keterangan tentang ketepatan penggunaan media JBB. Hal ini disebabkan banyak diantara mereka yang jarang mengakses Program Jogja Belajar Budaya sehingga enggan berkomentar. Selain itu informan juga mengatakan akan membukajikaitu dibutuhkan dalam kegiatan belajar mengajar saja.

Secara keseluruhan hasil audit dapat disimpulkan bahwa penggunaan media Program Jogja Belajar Budaya telah tepat sehingga tidak perlu berubah menggunakan media lain meskipun ada pendapat 32\% informan untuk beralih media. Usul ini sebenarnya tidak harus berganti media namun cukup ditambahkan atau dikembangkan melalui media sosial yang lain, misalnya Instagram dan Facebook.

Ketepatan pemilihan media yang digunakan dalam penyampaian pesan sangat besar pengaruhnya terhadap keberhasilan proses komunikasi yang terjadi. Hal ini sejalan dengan model komunikasi David K. Berlo atau lebih dikenal dengan model SMCR. Model ini mengacu bahwa proses komunikasi dipengaruhi oleh Source (sumber), Message (pesan), Channel (Saluran), dan Receiver (penerima).

Media memiliki peran penting dalam proses penyampaian sehingga pemilihan media memang harus tepat. Selain itu saluran komunikasi atau media yang baik digunakan hendaknya memiliki kriteria (1) baik menurut sasaran (2) dapat diterima banyak sasaran (3) mudah digunakan oleh banyak sumber maupun penerima (4) lebih ekonomis (5) cocok dengan pesan.

Hasil Audit program belajar budaya ditemukan tentang kejelasan arti pesan. Audit dokumen menjabarkan bahwa kejelasan arti pesan tidak bisa lepas dari proses penyampaian pesan yang terjadi. Terkait audit Program Jogja Belajar Budaya telah melakukan proses penyampaian pesan melalui cara primer dengan sosialisasi Program Jogja Belajar Budaya dan berbagai contoh tindakan yang mencerminkan masyarakat Jogja yang berbudaya. Pelayanan prima yang dilakukan menjadi salah satu indikator proses penyampaian pesan. Selain melalui proses primer, proses penyampaian pesan Program Jogja Belajar Budaya juga dilakukan dengan cara sekunder. Cara ini ditempuh dengan bantuan media. Internet menjadi pilihan utama dalam rangka penyampaian pesan tersebut. 
Hasil penelitian Program Jogja Belajar Budaya yang dilakukan ternyata memiliki respon berbeda. Informan ada yang menyatakan bahwa pesan Program Jogja Belajar Budaya mudah difahami, ringkas, simpel, tidak berteletele, menarik, informatif dan isinya sederhana. pernyataan tersebut menjadi pernyataan positif dan menunjukkan $60 \%$. Artinya pernyataan tersebut menunjukkan bahwa proses pesan yang dilakukan telah berhasil. Banyak pesan Program Jogja Belajar Budaya yang ingin disampaikan memiliki keberhasilan 60\%. Selebihnya 40\% menunjukkan informan kurang merespon. Sikap ini ditunjukkan karena informan jarang membuka apalagi mempelajari Program Jogja Belajar Budaya, sehingga pesan didalamnya tidak sampai.

Sesuai SOP dalam dokumen Balai Tekkomdik bahwa proses penyampaian pesan seperti terlihat gambar 4 .

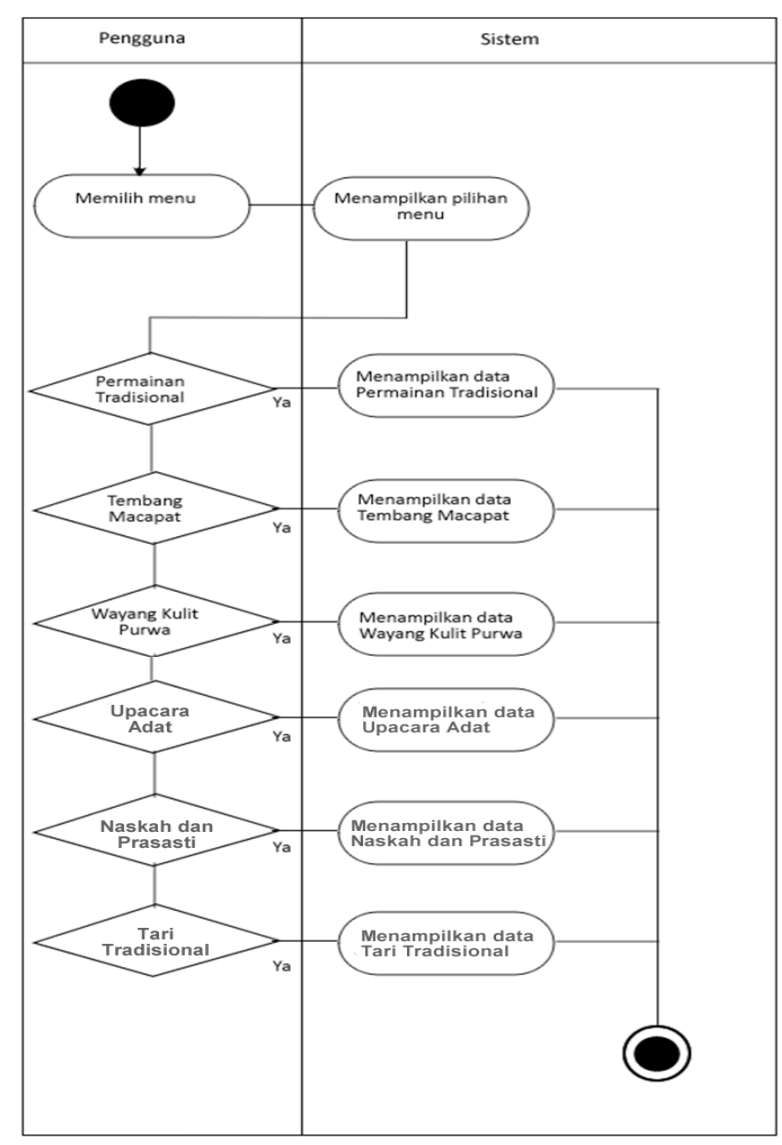

Gambar 4 Activity Diagram User
Audit dokumen menjelaskan bahwa penyampaian pesan dilakukan ketika pengguna mengakses Program Jogja Belajar Budaya. Jika Program Jogja Belajar Budaya sebagai media tidak dimanfaatkan maka pesan tidak akan sampai. Hal ini berkaitan dengan hasil audit yang menyatakan 40\% informan kurang merespon. Sikap ini diambil informan karena ada yang memang hanya membuka sekali ketika mendapatkan sosialisasi. Ada yang mengatakan malas membuka konten pembelajaran karena dianggap tidak efektif dan menghabiskan kuota internet, kecuali jika pihak Balai Tekkomdik juga turut memfasilitasi internet sebagai sarana pembelajaran.

Selain itu beberapa catatan hasil audit yang harus diperhatikan adalah (1) perencanaan waktu perlu diperhatikan demi keberhasilan tujuan yang ingin dicapai. Banyak yang mengeluhkan bahwa keterbatasan waktu menjadikan perencanaan program kurang maksimal. Hasil audit wawancara menyatakan beberapa informan mengatakan bahwa perencanaan yang kurang maksimal karena hanya ingin mengejar ketercapaian penyerapan anggaran sehingga hasil di belakang kurang maksimal, (2) isi pesan agar lebih dilengkapi sesuai target dalam Program Jogja Belajar Budaya. Selain itu isi pesan disesuaikan dengan kebutuhan pembelajaran di sekolah. Hal ini dimaksudkan agar Program Jogja Belajar Budaya menjadi maksimal pemanfaatannya. Keterlibatan guru MGMP Bahasa Jawa juga perlu dikaji ulang agar dapat memberikan manfaat yang saling menguntungkan, dan (3) pengembangan Program Jogja Belajar Budaya tergantung dari anggaran sehingga diharapkan pihak terkait mampu menyelesaikan masalah anggaran ini demi kebaikan Program Jogja Belajar Budaya yang akan datang. 


\section{Evaluasi Tahapan Output}

Audit pada tahap output tidak lepas dari perencanaan. Perencanaan yang baik kurang berarti apabila tidak diimbangi pelaksanaan kerja organisasi yang baik dan bertanggung jawab. Hal ini berkaitan dengan sumber daya manusia harus bekerja optimal demi mencapai tujuan program.

Audit dokumen pedoman Pyramid Model Of Research Salah satu indikasi yang harus dilakukan dalam tahap output adalah penyebaran pesan kepada target. Dalam hal ini tim Balai Tekkomdik berusaha menyampaikan pesan dalam Program Jogja Belajar Budaya dengan melaksanakan berbagai program dan kegiatan ataupun sosialisasi.

Tahapanoutputlebihbanyakberbicaratentang jumlah pesan yang dikirim dan disampaikan dari komunikator kepada komunikan. Tahapan ini tetap mengacu kolaborasi antara elemen audit komunikasi dan Pyramid Model Of Research digambarkan dalam gambar 5.

Gambar 5 menjelaskan audit program Jogja belajar budaya dalam tahapan output. Hasil audit menyatakan bahwa pengiriman pesan telah memenuhi jumlah yang besar. Pengiriman pesan melalui berbagai kegiatan yang ada di Balai Tekkomdik sebagai upaya saling

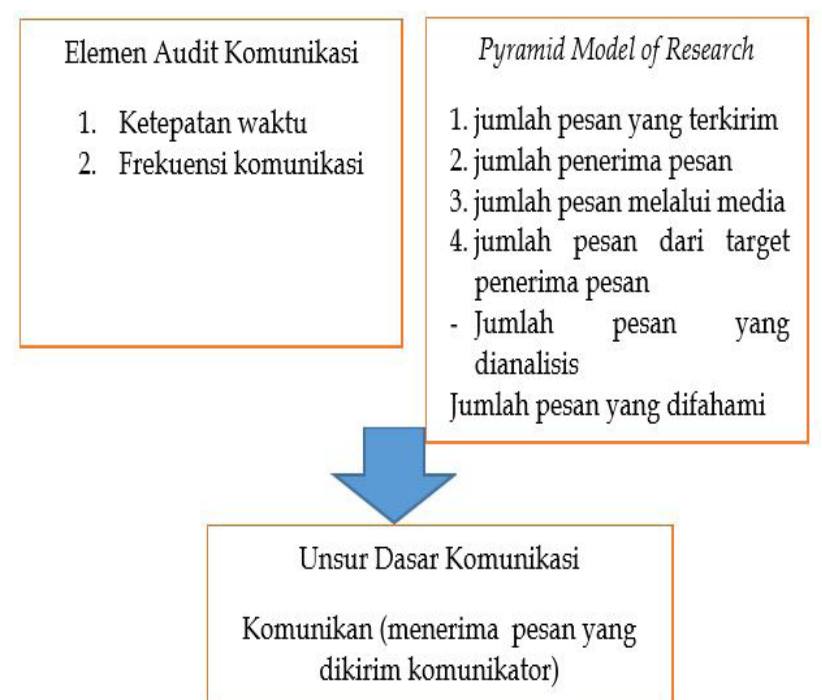

Gambar 5 Audit Komunikasi Program Jogja Belajar Budaya Tahap Output menguatkan. Banyaknya pesan yang dikirim diharapkan mampu mendongkrak keberhasilan tujuan Program Jogja Belajar Budaya. Pelaksanaan masing-masing kegiatan guna penyampaian pesan selalu dilaksanakan rutin baik melalui media ataupun secara langsung. Berdasarkan hasil penelitian pada tahap output, secara umum dapat dikatakan berhasil karena banyaknya jumlah pesan yang telah berhasil disampaikan kepada target. Meskipun begitu hasil audit beberapa informan mengatakan bahwa jumlah kegiatan sebagai sarana penyampaian pesan Program Jogja Belajar Budaya dirasa masih kurang mencukupi sehingga ada masukan agar kegiatan serupa dapat ditambah ke depannya sesuai kebutuhan di masyarakat.

Hasil audit dari fakta yang menarik dari tahap output adalah ketika proses penyampaian pesan Program Jogja Belajar Budaya dilaksanakan melalui kegiatan dan program lain yang ada di Balai agar saling menguatkan. Artinya di dalam Balai Tekkomdik terdapat struktur yang saling berkoordinasi dengan baik. Hal ini seperti apa yang dikemukakan Weick memandang struktur sebagai aktivitas yang lebih spesifik, sebagai aktivitas komunikasi. Struktur organisasi ditentukan oleh perilaku yang saling bertautan.

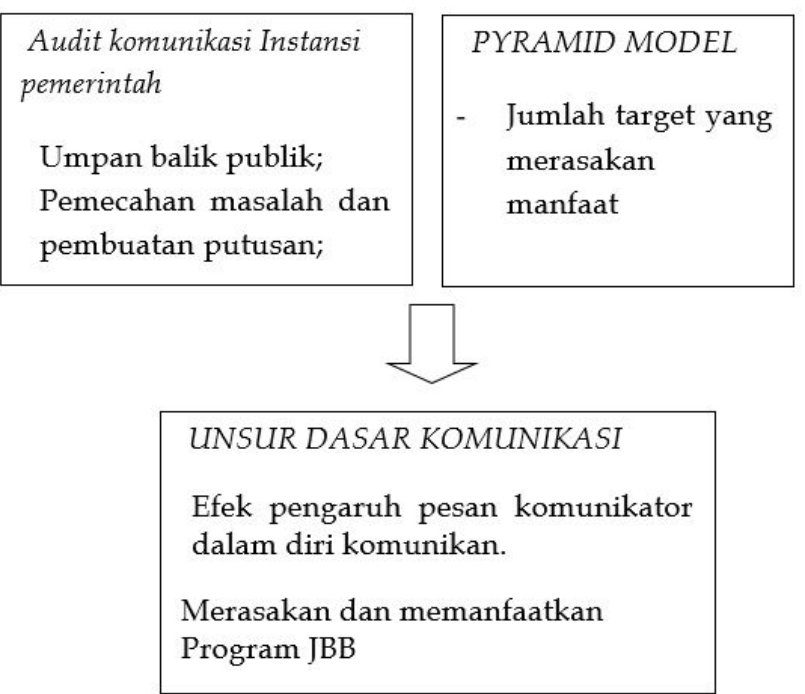

Gambar 6 Audit Komunikasi Program Jogja Belajar Budaya Tahap Outcome 


\section{Evaluasi Tahap Outcome}

Mengulas tentang audit pada tahap outcome tidak bisa lepas dari tujuan adanya Program Jogja Belajar Budaya. Outcome merupakan dampak yang diharapkan ada ketika target sasaran telah mendapatinput program.Artinya sasaran Program Jogja Belajar Budaya diharapkan ada perubahan sikap setelah adanya input mengenai program tersebut. Perubahan sikap berupa pemanfaatan Program Jogja Belajar Budaya dalam kehidupan sehari- hari. Gambar 6 menjelaskan audit program Jogja Belajar Budaya Tahap Outcome.

Hasil audit dokumen gambar 6 memperlihatkan bahwa gabungan ketiga elemen semua akan kembali kepada efek adanya Program Jogja Belajar Budaya yaitu kemanfaatan Program Jogja Belajar Budaya dalam kehidupan masyarakat. Maka audit dilanjutkan dengan mengungkap dua elemen guna mendapatkan jawaban kemanfaatan Program Jogja Belajar Budaya.

\section{Tertarik menerapkan Program Jogja Belajar Budaya dalam kehidupan}

Rasa tertarik ada ketika pertama kali mengenal sesuatu. Perasaan ini biasanya menyelip muncul saat tidak sengaja melihat atau menemukan sesuatu. Ketika orang telah tertarik akan dengan senang hati mencari informasi tentang hal yang membuatnya tertarik bahkan tidak menutup kemungkinan akan menyukai hingga mampu membawa nya kedalam kehidupan sehari- hari. Hal ini juga yang diharapkan dari keberadaan Program Jogja Belajar Budaya. Ketika orang telah tertarik maka dia akan berusaha untuk terus mencari informasi hingga mampu membawanya dalam kehidupan.

Peneliti mencoba mencari data ketertarikan komunikan terhadap Program Jogja Belajar Budaya. Hasil penelitian menunjukkan bahwa $82 \%$ informan tertarik menerapkan dalam kehidupan sehari-hari. Artinya ketertarikan ini ada dan berharap akan menuju fase memanfaatkan Program Jogja Belajar Budaya. Hasil audit wawancara beberapa informan menyatakan hal yang senada dengan informan 10 bahwa:
"Ketertarikan memanfaatkan Program Jogja Belajar Budaya ada, hal ini karena ingin ikut andil nguri- uri kabudayan nenek moyang agar tidak punah. Padahal efek budaya Jogja itu bagus jika diterapkan, misalnya tentang etika, unggah ungguh, kesopanan (wawancara 5 september 2019)“" Hasil audit dengan teknik wawancara kepada informan 9 yang berprofesi sebagai guru menyatakan hal yang hampir sama dengan informan 10 sebagai berikut;

"Kalau dibilang tertarik pasti tertarik karena fenomena saat initerutama anak muda sudah mulai hilang rasa kejawen nya, diharapkan adanya Program Jogja Belajar Budaya akan mampu mendidik yang berbudaya dan ber etika. Budaya Jawa memberikan efek positif untuk kepribadian anak." (wawancara 29 agustus 2019)

Secara keseluruhan hasil audit jika dilihat dari data wawancara informan banyak yang menyatakanbahwaadarasatertarikmemanfaatkan dalam kehidupan terbukti dari $82 \%$ menyatakan tertarik. Hal ini dibuktikan dengan pengakuan bahwa Budaya Jogja mampu mendidik anak beretika. Hasil audit yang lain terdapat 18\% informan yang menyatakan tidak tertarik dan merasa biasa saja. Hal ini dibuktikan dengan anggapan bahwa Budaya Jogja seperti budaya daerah lain yang tidak perlu diistimewakan.

\section{Manfaat Jogja Belajar Budaya}

Audit dokumen menjelaskan bahwa sebuah program yang telah direncanakan pasti dilandasi tujuan tertentu. Tujuan secara umum bahwa program tersebut ada agar bisa dimanfaatkan. Begitu juga halnya dengan Program Jogja Belajar Budaya dapat memberikan manfaat baik untuk dunia pendidikan maupun masyarakat yang membutuhkan. Dalam proses pembelajaran terdapat tiga tahapan (1) mengetahui (2) mengerti (3) memahami. Ketika seseorang dalam tahap awal dia berada di tahap pertama yaitu tahap mengetahui. Mengetahui terpusat pada ilmu pengetahuan dan hanya pada tarap melihat dan mendengar. Tahap berikutnya mengerti sebelum dia memahami. Mengerti tidak cukup 


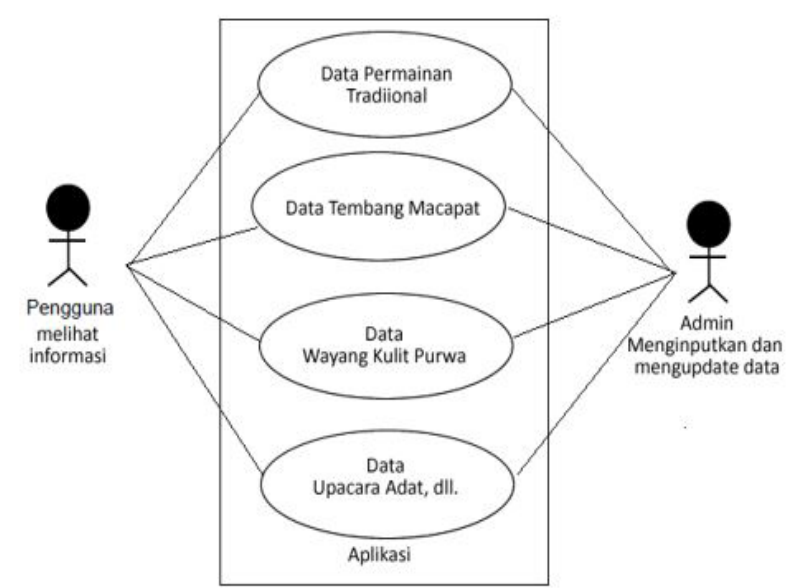

Gambar 7 SOP pengguna Program Jogja Belajar Budaya

melihat. Sedangkan tahap pemahaman tercermin dari kemampuan seseorang untuk memahami, mengetahui tentang sesuatu dan dapat memberikan penjelasan serta meniru hal tersebut. Ketika orang sudah paham maka secara reflek mengaplikasikan dalam kehidupan sehari- hari.

Terkait audit dalam fase manfaat program Jogja Belajar Budaya ini peneliti mengaudit data seberapa besar manfaat Program Jogja Belajar Budaya dengan kata lain peneliti mencari kebermanfaatan Program Jogja Belajar Budaya. Hasil audit menunjukkan bahwa 64\% informan menyatakan Program Jogja Belajar Budaya baru tahap tahu, mengerti dan sekedar menambah wawasan saja. Selebihnya yang memahmi hanya $6 \%$ dan informan yang belum bisa merasakan mencapai $30 \%$.

Secara umum hasil audit menunjukkan kebermanfaatan Program Jogja Belajar Budaya belum tercapai dilihat dari jumlah informan yang paham hanya $6 \%$ saja. Di sisi lain keberadaan Program Jogja Belajar Budaya hanya sebatas informasi guna menambah wawasan saja. Berarti $64 \%$ dari informan tersebut beranggapan bahwa Program Jogja Belajar Budaya belum masuk tahap pemanfaatan pesan yang ada di dalamnya.

Hal ini juga dikuatkan dengan audit wawancara beberapa informan yang menyatakan bahwa kedalaman pesan yang ada belum mencapai tingkat dasar dan baru sebatas informasi saja. Selain itu audit dokumen menyatakan SOP juga menggambarkan bahwa belum ada kategori dalam pemanfaatan Program Jogja Belajar Budaya seperti gambar 7.

Hasil audit SOP tersebut menunjukkan Program Jogja Belajar Budaya yang telah diinput admin hanya sampai pada pengguna melihat informasi. Selebihnya untuk pemanfaatan belum digambarkan di SOP. Jadi hasil audit yang menunjukkan bahwa 64\% informan hanya menganggap Program Jogja Belajar Budaya sebagai sebuah informasi telah sesuai dengan SOP Balai Tekkomdik.

Audit program Jogja Belajar Budaya ini, hasil akhir adalah kemanfaatan Program Jogja Belajar Budaya. Manfaat dapat dirasakan jika telah mencapai fase memahami, dengan begitu akan mampu memanfatkannya dalam kehidupan. Namun dari hasil penelitian hanya $6 \%$ informan yang menyatakan memahami. Kedepan diharapkan Balai Tekkomdik mampu memperbaikikemacetan agar dapat lebih baik lagi.

\section{Peranan Audit Komunikasi Program Jogja Belajar Budaya}

Audit komunikasi merupakan kajian mendalam dan menyeluruh tentang pelaksanaan sistem komunikasi keorganisasian dan memiliki tujuan meningkatkan efektivitas organisasi. Audit memperlihatkan proses komunikasi mampu diperiksa, dievaluasi dan diukur secara cermat dn sistematis seperti halnya keuangan.

Kegiatan komunikasi merupakan bagian dari sistem atau program komunikasi. Hal ini yang menjadikan komunikasi dapat diukur demi perbaikan kualitas dan kinerja organisasi. Temuan ini diharapkan mampu meningkatkan efektivitas dan efisiensi. Hasil audit komunikasi berguna untuk memperbarui sistem komunikasi sesuai kebutuhan dan kondisi internal maupun eksternal organisasi, sebagaimana temuan Juditha (2014) dan Lestari, Astari, dan Asyrafi (2019) tentang audit penyiaran, bedanya audit ini tentang siaran program Jogja Belajar Budaya. Inilah kebaruan penetian ini bahwa program Jogja belajar Budaya selama ini belum dilakukan audit secara terbuka. 


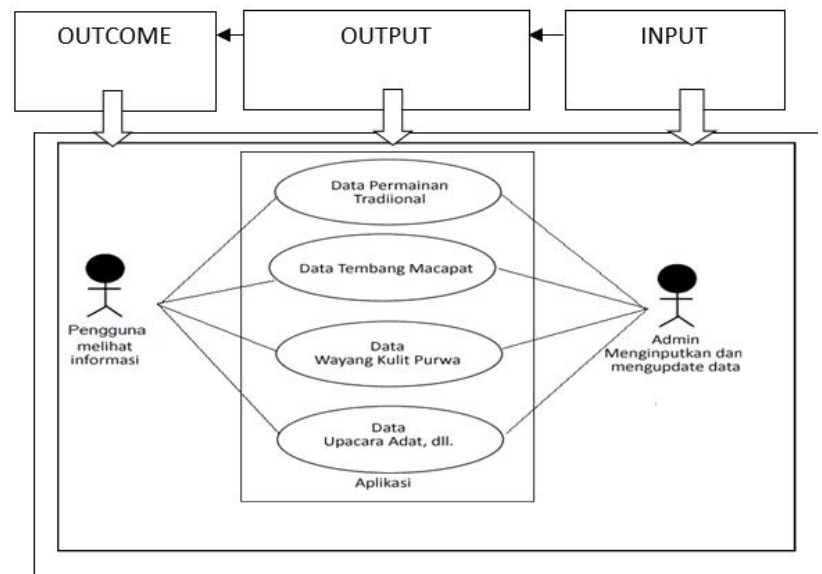

Gambar 8 Penggabungan SOP Balai dengan Tahapan Audit

Seperti halnya dengan audit komunikasi Program Jogja Belajar Budaya Balai Tekkomdik Dinas Dikpora DIY. Menurut hasil audit dokumen bahwa selama Program Jogja Belajar Budaya ada belum pernah diadakan audit komunikasi, hanya sebatas koordinasi dan evalusi seperti program yang lain dan belum sesuai prosedur audit komunikasi. Itupun banyak yang mengeluhkan bahwa kondisi saat ini belum pernah diadakan evaluasi program dan kegiatan. Hal ini disebabkan pergantian pimpinan dengan tidak disertai transfer knowledge.

Sesuai Peraturan Menteri Negara Pendayagunaan Aparatur Negara dan Reformasi Birokrasi Republik Indonesia Nomor 27 Tahun 2011 bahwa salah satu tujuan audit komunikasi instansi pemerintah adalah mengetahui kekuatan, kelemahan, peluang dan ancaman sebuah program dalam hal ini Program Jogja Belajar Budaya (analisis SWOT).

Hasil audit dianalisis kelemahan Program Jogja Belajar Budaya dengan melakukan audit komunikasi melalui prosedur sederhana dengan melihat pelajaran yang dapat diambil dari sesuatu yang telah berlalu. Temuan dalam audit jika melihat keadaan di lapangan baik melalui audit wawancara ataupun audit dokumen maka peneliti mendapatkan temuan antara lain: a) Kurang adanya sosialisasi secara mendalam. Sosialisasi yang dilakukan sekedar informasi saja belum sampai ke praktek penerapan program. Selain itu peserta sosialisasi masih mengeluhkan kurangnya frekuensi sosialisasi yang dilakukan; b) Terkait adanya keluhan kekurangan isi pesan dan kesesuaian pesan dan kedalaman pesan. Hal ini berhubungan pula dengan keterlibatan guru MKKS Bahasa Jawa dalam pengisian Program Jogja Belajar Budaya. Selain itu keterbatasan waktu menjadikan kinerja kurang maksimal bahkan ada anggapan bahwa seolah adanya program ini hanya karena penyerapan anggaran saja. Sedangkan mengenai isi Program Jogja Belajar Budaya yang stagnan disebabkan minimnya anggaran tentang konten kebudayaan. Pihak yang bertugas memproduksi media pembelajaran lebih memilih tema lain yang dirasa lebih dibutuhkan dan diminati daripada konten bertema kebudayaan. Masalah yang berhubungan dengan kedalaman isi yang dirasa hanya sebatas informasi disebabkan keterbatasan waktu sehingga kerja tim kurang maksimal. Hal ini berimbas pada materi yang ada seolah hanya dipermukaan saja. Menurut SOP balai memang program ini hanya berorientasi output belum mengarah pada outcome (Gambar 7). c) Media yang digunakan secara umum telah tepat, namun masih adanya keluhan jika media kurang cocok diterapkan untuk usia lanjut; d) Salah satu indikasi keberhasilan Program Jogja Belajar Budaya ini adalah kemanfaatannya, dan hal ini dapat terlihat minimal dari jumlah visitor. Semakin banyak visitor, diharapkan mampu memanfatkan dalam kehidupan. Ternyata jumlah visitor masih jauh dari harapan sehingga perlu diadakannya perbaikan guna peningkatan jumlah visitor. Hal ini senada dengan temuan dari informan yang memahami Program Jogja Belajar Budaya 6\% saja. Audit dilihat dari sisi kelebihan Program Jogja Belajar Budaya diuraikan dengan pengelompokan haasil audit sebagai penemuan keunggulan dari proses audit yang telah dilaksanakan. Peneliti menguraikan temuan kelebihan dari Program Jogja Belajar Budaya 
setelah melalui proses komunikasi dari berbagai sisi sesuai model SMCR. Tampilan Program Jogja Belajar Budaya sebagai Source, sumber informasi sudah menarik sehingga informan mengatakan bahwa Program Jogja Belajar Budaya menarik, informatif meskipun masih perlu diadakan beberapa pembenahan sesuai masukan informan. Dilihat dari kejelasan message, isi pesan hasil penelitian menyatakan arti pesan mudah dipahami meskipun tetap ada tanggapan yang kurang merespon dengan baik. Hasil audit ketepatan penggunaan Channel, media yang digunakan masuk ketagori tepat. Hampir setengah informan menyatakan penggunaan media sesuai. Ada pendapat yang menyatakan bahwa Program Jogja Belajar Budaya sebaiknya merambah ke media sosial agar lebih mudah dikenal masyarakat. Dari segi Receiver, penerima program banyak memberikan respon tertarik menggunakan program Jogja Belajar Budaya dalam kehidupan sehari-hari. Infirman banyak yang menyatakan tertarik, meskipun ada sedikit yang menyatakan tidak tertarik. Hal ini menunjukkan bahwa sebenarnya banyak yang tertarik dengan Budaya Jogja hanya saja kurangnya media, informasi yang dapat menuntun ke arah yang diinginkan. Tantangan bagi Balai Tekkomdik untuk bisa mewujudkannya.

\section{Simpulan}

Berdasarkan analisis hasil audit Program Jogja Belajar Budaya yang dilakukan maka dapat disimpulkan bahwa hasil audit tahapan input Program Jogja Belajar Budaya pada dasarnya telah berjalan dengan baik sesuai SOP yang telah ada. Proses tahapan telah dilalui dengan adanya workshop, FGD, uji coba maupun proses yang tertuang didalam aturan. Ada temuan tentang isi dalam Program Jogja Belajar Budaya masih kurang mendalam dan terkesan hanya sebatas informasi saja. Hal ini terkendala waktu yang terlalu pendek sehingga kerja tim menjadi kurang maksimal dan menyebabkan kurangnya bobot materi program bahkan terkesan hanya sebatas penyerapan anggaran saja.
Hasil audit tahapan output Program Jogja Belajar Budaya menunjukkan jumlah pesan yang disampaikan telah mencukupi dan sesuai target. Penyampaian pesan dilakukan melalui berbagai program kegiatan di Balai Tekkomdik. Hal ini berarti adanya koordinasi seperti teori informasi organisasi Weick yang memandang struktur sebagai aktivitas yang lebih spesifik sebagai aktivitas komunikasi. Struktur oraganisasi ditentukan oleh perilaku yang saling bertautan.

Hasil audit tahapan outcome audit komunikasi Program Jogja Belajar Budaya menunjukkan bahwa tingkat ketertarikan memanfaatkan progran JBB dalam kehidupan sehari- hari tinggi. Namun temuan ketika dilihat dari segi kemanfaatan ternyata masih sangat rendah. Hal ini bisa disebabkan saat perencanaan program tidak berorientasi pada outcome dan hanya sebatas output saja. Selain itu kelengkapan dan kedalaman isi Program Jogja Belajar Budaya juga belum sesuai dengan yang diharapkan. Sesuai SOP yang ada saat program ini direncanakan hanya terlihat bahwa keluaran program hanya sebatas output dan informasi saja.

Setelah peneliti memberikan kesimpulan berdasarkan hasil audit maka peneliti memberikan saran atau rekomendasi. Saran ini diharapkan dapat menjadi pertimbangan Balai Tekkomdik dalam mengelola Program Jogja Belajar Budaya agar Program Jogja Belajar Budaya bisa menjadi lebih baik. Selain itu diharapkan dapat menjadi acuan memperbaiki kinerja organisasi dan memaksimalkan kinerja dalam pelaksanaan suatu program untuk publiknya. Penelitian audit komunikasi Program Jogja Belajar Budaya diharapkan kehadirannya mampu menjadi bahan rujukan ataupun referensi bagi penelitian selanjutnya khususnya penelitian tentang audit komunikasi program dan mampu memberikan sumbangan pemecahan masalah.

Adapun rekomendasi praktis penelitian audit ini yaitu Bagi pemerintah, adanya Peraturan Menteri Negara Pendayagunaan Aparatur Negara dan Reformasi Birokrasi 
Republik Indonesia Nomor 27 Tahun 2011 tentang audit komunikasi pemerintah agar bisa diimplementasikan guna meningkatkan efisiensi dan efektivitas instansi, Bagi masyarakat agar mampu memberikan masukan pertimbangan dalam menyusun program dan kebijakan khususnya Program Jogja Belajar Budaya; Bagi pemerintah diharapkan untuk mencapai perbaikan proses komunikasi serta peningkatan target yang ingin dicapai Program JB Budaya di tahun- tahun berikutnya. Hasil audit komunikasi dapat memberikan informasi yang penting untuk efisiensi, kredibilitas, dan ekonomi dari kebijakan, praktik, dan Program Jogja Belajar Budaya. Hasil penelitian audit komunikasi Program Jogja Belajar Budaya diharapkan mampu dimanfaatkan untuk pengembangan atau restrukturisasi fungsi- fungsi, petunjuk dan anggaran Program Jogja Belajar Budaya. Bagi pihak Balai Tekkomdik dapat berkolaborasi dengan dinas lain untuk kepentingan pengisian konten pembelajaran budaya Yogyakarta.

\section{Daftar Pustaka}

Hardjana, A. (2000). Audit Komunikasi. PT. Grasindo. Jakarta.

Koesmastuti, R. H. (2015). Audit Komunikasi dalam Organisasi Budaya Timur. Jurnal Pengembangan Humaniora. 15(2).
Juditha, C. (2014). Etika Jurnalisme Bencana Dalam Berita Televisi (Bencana Gunung Berapi Sinabung Di Tvone). Jurnal Komunikasi, 6(1). http://dx.doi.org/10.24912/jk.v6i1.22 Lestari, P., Astari, D. W., \& Asyrafi, A. L. (2019). Audit of Disaster Communication on TVOne Kabar Petang Program. Jurnal Komunikasi Ikatan Sarjana Komunikasi Indonesia, 4(2), 116-127. https://doi.org/10.25008/jkiski.v4i2.332 Moleong. (2008). Metodologi Penelitian Kualitatif. Bandung: Rosdakarya Panghegar, S. F. (2013). Audit Komunikasi Organisasi Horisontal Departemen Front Office Singgasana Hotel Surabaya. Jurnal E-Komunikasi Program Studi Ilmu Komunikasi Universitas Kristen Petra Surabaya, 1(1) Prayudi. (2016). Strategic Public Relation. Komunikasi UPN Press Ramadani, D., Lestari, P., \& Susilo, E. (2015). Audit Komunikasi Organisasi Wahana lingkungan Hidup (WALHI). Jurnal Ilmu Komunikasi ASPIKOM, 2(4) Republik Indonesia. (2011). Peraturan Menteri Pendayagunaan Aparatur Negara dan Reformasi Birokrasi Republik Indonesia Nomor 27 Tahun 2011 Tentang Pedoman Umum Audit Komunikasi di Lingkungan Instansi Pemerintah, Jakarta: 2011. 